\title{
Microbial biomass, growth, and respiration associated with submerged litter of Phragmites australis decomposing in a littoral reed stand of a large lake
}

\author{
D. Komínková*, K. A. Kuehn" ${ }^{* *}$ N. Büsing, D. Steiner, M. O. Gessner ${ }^{* * *}$ \\ Department of Limnology, Swiss Federal Institute for Environmental Science and Technology (EAWAG/ETH), \\ Limnological Research Center, 6047 Kastanienbaum, Switzerland
}

\begin{abstract}
This study examined the microbial dynamics associated with decomposing litter of the widespread emergent macrophyte Phragmites australis in a littoral reed stand of a large lake. Standing dead leaf and stem litter were collected, placed into fine and coarse mesh litter bags, and submerged in the reed stand. Litter bags were retrieved periodically and analyzed for fungal and bacterial biomass, fungal growth rates and production, rates of microbial respiration, litter mass loss, nutrient concentrations ( $\mathrm{N}$ and $\mathrm{P}$ ), and rates of dissolved organic carbon (DOC) release. Microbial biomass associated with both leaf and stem litter (12 to $85 \mathrm{mg} \mathrm{C} \mathrm{g}^{-1}$ detrital C) was predominantly fungal (always $\geq 90 \%$ of the total biomass), even though bacterial biomass ( 0.13 to $5.6 \mathrm{mg} \mathrm{C} \mathrm{g}^{-1}$ detrital C) increased and fungal biomass decreased or remained constant as litter decay proceeded. Although rates of fungal growth $\left(0.02\right.$ to $\left.0.08 \% \mathrm{~h}^{-1}\right)$ and production (leaves only; 3 to $51 \mu \mathrm{g} \mathrm{C} \mathrm{g}^{-1}$ detrital $\mathrm{C} \mathrm{h}^{-1}$ ), and rates of microbial respiration (11 to $257 \mu \mathrm{g} \mathrm{g} \mathrm{g}^{-1}$ detrital $\mathrm{C} \mathrm{h}^{-1}$ ) decreased following litter submergence, fungi continued to be metabolically active in both leaf and stem litter. Significant differences in fungal and bacterial biomass, fungal production rates, and rates of respiration were observed between leaf and stem material, with leaves often having 5 times higher values than corresponding stems. Rates of mass loss differed significantly between leaf litter in fine and coarse mesh bags, with less than $10 \%$ of the initial mass remaining in coarse mesh bags after $86 \mathrm{~d}$, versus nearly $60 \%$ remaining in fine mesh bags. Nitrogen and P concentrations of leaf litter enclosed in fine mesh bags increased during litter decay, whereas $\mathrm{N}$ concentrations of leaf litter in coarse mesh bags remained unchanged and P concentrations decreased. Both $\mathrm{N}$ and $\mathrm{P}$ concentrations of stem litter were similar among litter bags and varied little throughout the study period. Results obtained in this study indicate that significant changes in microbial colonization and activity associated with $P$. australis litter can occur following the collapse of standing dead plant matter to the water. Furthermore, these findings suggest that fungi are active on submerged litter and thus play a vital role in the decomposition of $P$. australis litter in the aquatic environment.
\end{abstract}

KEY WORDS: Litter decomposition · Phragmites australis · Wetland - Microbial productivity · Fungi · Nutrients $\cdot$ Respiration $\cdot$ Growth efficiency

Resale or republication not permitted without written consent of the publisher

\section{INTRODUCTION}

Emergent macrophytes often form the greatest portion of the organic matter produced in wetlands, including lit-

Present addresses:

*Institute for Environmental Studies, Charles University, Prague, Czech Republic

${ }^{* *}$ Department of Biology, 316 Mark Jefferson Hall, Eastern Michigan University, Ypsilanti, Michigan 48197, USA ${ }^{* * *}$ Corresponding author. E-mail: gessner@eawag.ch toral zones of lakes (e.g., Wetzel 1990). For example, net above-ground production of vigorous stands of the common reed Phragmites australis frequently exceed $1 \mathrm{~kg}$ $\mathrm{m}^{-2} \mathrm{yr}^{-1}$, thus representing one of the most productive types of ecosystems in temperate regions (Wetzel 1990, Květ \& Westlake 1998). The bulk of this plant biomass tends not to be consumed during the growing season (Dvořák \& Imhof 1998), but eventually enters the detrital pool and is broken down by fungi, bacteria, and detritusfeeding invertebrates (Polunin 1984). 
In many emergent macrophytes, such as Phragmites australis, abscission and collapse of plant material to the sediment or overlying surface waters typically do not occur immediately following shoot senescence and death. As a result, large amounts of dead plant matter remain standing within wetland habitats (Findlay et al. 1990, Lee 1990, Wetzel \& Howe 1999), and are colonized and decomposed in an upright aerial position (Newell 1993, Newell et al. 1995, Bärlocher \& Biddiscombe 1996, Kuehn \& Suberkropp 1998a,b Kuehn et al. 1999, Gessner 2000b). In P. australis, leaves are normally dropped within a few months following senescence, whereas dead stems can remain in a standing position for up to several years (e.g., Granéli 1990). These findings imply that $P$. australis litter may undergo considerable initial microbial colonization and decay prior to its entry into the aquatic environment.

Previous investigations examining the dynamics of Phragmites australis litter under submerged conditions have focused on rates of mass loss (Polunin 1984, Hietz 1992), patterns of microbial respiration (Hargrave 1972, Mason \& Bryant 1975, Mason 1976, Andersen 1978, Polunin 1982), degradative enzymes (Goulder 1990, Tanaka 1993a), nutrient concentrations (Úlehlová 1990, Hietz 1992), and bacterial numbers and biomass associated with plant litter (Oláh 1972, Úlehlová 1978, Tanaka \& Tezuka 1982, Tanaka 1993b, Anesio et al. 1999). To date, very little quantitative data are available concerning the dynamics of both bacteria and fungi associated with litter of $P$. australis (Tanaka 1991, 1993b, Denward et al. 1999) and other emergent macrophytes (Kuehn et al. 2000). Most of these previous studies were conducted using plant material that had been collected before natural senescence and death occurred, and often this material was manipulated (e.g., oven dried, ground) prior to submergence (e.g., Mason \& Bryant 1975, Tanaka \& Tezuka 1982). Thus, the initial standing decay phase was potentially circumvented, or in the case of oven drying, an already active inhabitant microbial community was extinguished (Newell 1993). As a consequence, these experimental conditions may have resulted in an inaccurate description of the microbial dynamics during submerged plant litter decay.
The present study was conducted to examine the dynamics of bacteria and fungi associated with Phragmites australis leaf and stem litter that falls into the water under more natural conditions, and to provide baseline information on the performance of microbial assemblages associated with decaying $P$. australis litter in a lacustrine freshwater environment.

\section{METHODS}

Study site. The present study was conducted in a littoral reed stand on the southeastern shore of Lake Neuchâtel, an oligotrophic hardwater lake located in western Switzerland ( $\left.46^{\circ} 54^{\prime} \mathrm{N}, 6^{\circ} 54^{\prime} \mathrm{E}\right)$ (Table 1). The common reed Phragmites australis is the dominant emergent macrophyte in this lake, forming nearly monospecific stands on a predominantly silty sediment (20 $\mu \mathrm{m}$ mean particle size). Littoral and associated wetland stands of $P$. australis around Lake Neuchâtel are classified as sites of national importance, since they represent the most extensive reed stands and harbor the greatest species richness within Switzerland. The

Table 1. Selected characteristics of Lake Neuchâtel and the littoral reed stand where the study was conducted. Surface water from the center of the lake was collected in November and March between 1994 and 1999 ( $\mathrm{n}=6$ to 9) and analyzed by the Environmental Protection Service of the Canton Neuchâtel. SRP = soluble reactive phosphorus, $\mathrm{TP}=$ total phosphorus, $\mathrm{DOC}=$ dissolved organic carbon. Values indicate mean $\pm 1 \mathrm{SD}$

\begin{tabular}{|c|c|c|}
\hline Parameter & Mean \pm SD & $\mathrm{n}$ \\
\hline \multicolumn{3}{|l|}{ Lake morphometry } \\
\hline Lake surface area $\left(\mathrm{km}^{2}\right)$ & 215 & \\
\hline Volume $\left(\mathrm{km}^{3}\right)$ & 13.8 & \\
\hline Maximum depth (m) & 153 & \\
\hline Mean depth (m) & 64 & \\
\hline \multicolumn{3}{|l|}{ Water chemistry } \\
\hline Conductivity $\left(\mu \mathrm{S} \mathrm{cm}^{-1}\right)$ & $280 \pm 27$ & 9 \\
\hline Total alkalinity $\left(\mathrm{mmol} \mathrm{l}^{-1}\right)$ & $3.1 \pm 0.1$ & 6 \\
\hline $\mathrm{pH}$ & $8.23 \pm 0.08$ & 8 \\
\hline $\operatorname{SRP}\left(\mu g \mathrm{l}^{-1}\right)$ & $4.1 \pm 1.9$ & 7 \\
\hline $\mathrm{TP}\left(\mu \mathrm{g} \mathrm{l}^{-1}\right)$ & $11.7 \pm 4.7$ & 7 \\
\hline $\mathrm{NH}_{4}{ }^{+}-\mathrm{N}\left(\mu \mathrm{g} \mathrm{l}^{-1}\right)$ & $25.9 \pm 13.3$ & 6 \\
\hline $\mathrm{NO}_{2}^{-}-\mathrm{N}\left(\mu \mathrm{g} \mathrm{l}^{-1}\right)$ & $3.0 \pm 2.0$ & 6 \\
\hline $\mathrm{NO}_{3}^{-}-\mathrm{N}\left(\mathrm{mg} \mathrm{l}^{-1}\right)$ & $1.1 \pm 0.2$ & 7 \\
\hline $\mathrm{DOC}\left(\mathrm{mg} \mathrm{l}^{-1}\right)$ & $1.8 \pm 0.2$ & 7 \\
\hline \multicolumn{3}{|l|}{ Reed stand characteristics } \\
\hline Approximate size examined (m) & $30 \times 50$ & \\
\hline Range of water depth along transect (m) & $0.3-1.0$ & \\
\hline Shoot density $\left(\mathrm{m}^{-2}\right)$ & $42 \pm 11$ & 6 \\
\hline Shoot height (m) & $3.11 \pm 0.35$ & 31 \\
\hline Basal culm diameter $(\mathrm{cm})$ & $0.99 \pm 0.11$ & 31 \\
\hline Maximum above-ground biomass $\left(\mathrm{g} \mathrm{m}^{-2}\right)^{\mathrm{a}}$ & $2519 \pm 867$ & 6 \\
\hline \multicolumn{3}{|c|}{$\begin{array}{l}{ }^{a} \text { Estimated at the end of the growing season }(31 \text { August } 1998) \text { by harvesting } \\
\text { Phragmites australis plant matter within } 0.25 \mathrm{~m}^{-2} \text { quadrats }(\mathrm{n}=6) \approx \text { annual } \\
\text { net above-ground production }\end{array}$} \\
\hline
\end{tabular}


reed stand examined in the present study is located northwest of the village of Forel, between Chevroux and Estavayer le Lac.

Field procedures. Fully brown leaf blades of Phragmites australis were collected on 1 November 1998 from that year's growing season shoots. Leaf blades were removed from shoots at mid-height (ca $1.5 \mathrm{~m}$ ), pooled, and subsamples (ca $9.5 \mathrm{~g}$ fresh mass) placed into either fine $(500 \mu \mathrm{m})$ or coarse $(7 \mathrm{~mm})$ mesh litter bags (approx. size $30 \times 10 \mathrm{~cm}$ ). In contrast, standing dead stem material of $P$. australis, including attached leaf sheaths, was collected (October) from previous years' growth, and thus represented litter which had undergone at least 1 yr of standing decay. Standard stem sections comprising 2 adjacent nodes and the internode were cut from shoots at mid-height, pooled, and subsamples (ca $12 \mathrm{~g}$ fresh mass) placed into litter bags (as above). On 1 November 1998, the litter bags were attached to lines secured to bamboo sticks and placed in the water within 4 randomly selected plots (approx. $4 \times 1 \mathrm{~m}$ ) along a $50 \mathrm{~m}$ transect through the reed stand, which ran parallel to the shoreline. This procedure allowed litter material to sink naturally to the sediment surface when sufficiently soaked. Water depth along the transect ranged from 0.3 to $1.0 \mathrm{~m}$ during the study. One bag of each mesh and litter type was immediately collected from each plot and returned to the laboratory for determination of fresh mass to ash-free dry mass (AFDM) ratios, initial plant litter associated biomass of fungi and bacteria, fungal growth rates, rates of microbial respiration, litter nutrient concentrations ( $\mathrm{N}$ and $\mathrm{P}$ ), and release of dissolved organic carbon (DOC). Thereafter, litter bags were retrieved periodically, placed in a cooler, and returned to the laboratory for analyses as detailed below. Data analyses were conducted using SYSTAT (Wilkinson et al. 1992) and values were considered significant at the $\mathrm{p}<0.05$ level. All values are reported as the means \pm 1 standard error (SE) or, in the case of nonlinear regression analysis, the asymptotic standard error (ASE).

Mass loss and nutrient content. Leaf and stem material was removed from litter bags and washed of adhering sediment and macroinvertebrates. Subsamples of leaf blades (ca $0.1 \mathrm{~g}$ ) and stem material (ca $1.0 \mathrm{~g}$ ) were cut and used for determination of microbial parameters and DOC release (see below). The remaining litter was lyophilized for $24 \mathrm{~h}$ (Leybold Inc., model Liovac GT2) and ground (0.2 mm mesh, Retsch centrifugal mill). The AFDM of leaf and stem material was determined following combustion $\left(5 \mathrm{~h}\right.$ at $550^{\circ} \mathrm{C}$ ) of litter subsamples. Nitrogen and phosphorus concentrations were determined spectrophotometrically following digestion of ground subsamples (5 to $10 \mathrm{mg}$ ) in peroxodisulphate (Gessner et al. 1998); values were corrected for residual moisture. The percentage of the AFDM of plant material remaining in litter bags was calculated as the sum of the remaining bulk mass plus the mass of subsamples removed for microbial analyses and determination of DOC release from litter. Nonlinear regression analysis was used to calculate exponential decay rate coefficients $(-k)$ according to the model $\left(m_{t}=m_{0} \times\right.$ $\left.\mathrm{e}^{-k t}\right)$, where $m_{t}$ is the AFDM at time $t(\mathrm{~d})$ and $m_{0}$ is the initial AFDM. Litter carbon was assumed to be $50 \%$ of AFDM (Gessner 2000a).

Bacterial biomass. Bacterial numbers associated with litter were determined by epifluorescence microscopy after staining with 4',6-diamidino-2-phenylindole (DAPI) (Porter \& Feig 1980). Subsamples of leaf and stem litter were placed in $20 \mathrm{ml}$ glass scintillation vials containing $10 \mathrm{ml}$ of $2 \%(\mathrm{v} / \mathrm{v})$ filtered $(0.2 \mu \mathrm{m})$ formalin containing sodium pyrophosphate buffer $(0.1 \%$ $\mathrm{w} / \mathrm{v})$. Additional subsamples of corresponding leaf and stem material were dried at $105^{\circ} \mathrm{C}$ and AFDM determined. Bacterial cells attached to litter samples were detached by ultrasonic probe sonication (Branson 250, power output $70 \mathrm{~W}$ ) for $3 \mathrm{~min}$. Prior laboratory tests had determined these conditions to be adequate for efficient removal of attached bacteria from decaying Phragmites australis litter (Büsing \& Gessner unpubl.). After sonication, samples were vortexed and after $10 \mathrm{~s}$ aliquots were taken (50 or $100 \mu \mathrm{l}$ ) and placed into a vacuum filtering apparatus containing $3 \mathrm{ml}$ of sterile distilled water (0.2 $\mu \mathrm{m}$ filtered and autoclaved). An additional $3 \mathrm{ml}$ of sterile distilled water was then added to ensure a homogenous suspension of bacterial cells prior to filtration. To this mixture, $50 \mu \mathrm{l}$ of a $0.1 \mathrm{mg}$ $\mathrm{ml}^{-1}$ DAPI solution was added and allowed to incubate for $7 \mathrm{~min}$ in the dark prior to filtration. Samples were then filtered (vacuum at ca 600 mbar) through black polycarbonate filters $(0.2 \mathrm{~mm}$ pore size, Millipore GTBP) supported by a nitrocellulose backing filter (0.45 mm pore size). Polycarbonate filters were removed from the filtering apparatus and mounted on glass slides in Cargille immersion oil (Type A, Formula 1248). Bacterial cells were assigned to 8 categories according to size and shape, and cells enumerated (1000× magnification) in a minimum of 10 fields $(\geq 500$ cells) using a Zeiss Axiolab epifluorescence microscope. Bacterial biovolume $\left(V, \mu^{-3}\right)$ for each size class was derived from length $(l)$ and width $(w)$ estimates using the formula: $V=w^{2} / 4 \times(1-w) \times \pi+w^{3} / 6 \times \pi$. Biovolume estimates were converted to bacterial carbon (fg C) using a formula $\left(\mathrm{C}=89.5 \times V^{0.59}\right)$ that accounts for size-dependent differences in carbon density of bacterial cells (Simon \& Azam 1989).

Fungal biomass and production. Fungal biomass associated with decomposing leaf and stem litter was estimated by the extraction and quantification of ergosterol from plant litter (Gessner \& Newell 1997). Frozen samples were lyophilized, weighed, and ergos- 
terol extracted in alcoholic $\mathrm{KOH}(0.8 \% \mathrm{KOH}$ in methanol, extraction volume $10 \mathrm{ml}$ ) for $30 \mathrm{~min}$ at $80^{\circ} \mathrm{C}$ in tightly capped tubes with constant stirring. The resultant crude extract was cleaned by solid phase extraction (Gessner \& Schmitt 1996), and ergosterol was purified and quantified by high pressure liquid chromatography (HPLC). A LichroSpher 100 RP-18 column $(0.46 \times 25 \mathrm{~cm})$ (Merck Inc.) connected to a Jasco AS950 autosampler and PU-980 liquid chromatography system was used for separation and analysis. The mobile phase was HPLC grade methanol at a flow rate of $1.5 \mathrm{ml} \mathrm{min}{ }^{-1}$. Ergosterol was detected at $282 \mathrm{~nm}$ using a Jasco UV-970 UV/VIS detector (retention time $=$ ca $8 \mathrm{~min}$ ), and was identified and quantified based on comparison with ergosterol standards (Fluka Chemical Co.). Ergosterol was converted to fungal carbon assuming a conversion factor of $10 \mu \mathrm{g}$ ergosterol $\mathrm{mg}^{-1}$ fungal $\mathrm{C}$ and $50 \% \mathrm{C}$ in fungal dry mass (Gessner \& Newell 1997).

Instantaneous growth rates of fungi were determined from rates of $\left[{ }^{14} \mathrm{C}\right]$ acetate incorporation into ergosterol (Gessner \& Newell 1997). Subsamples of leaves and culms from litter bags were incubated in sterile $20 \mathrm{ml}$ glass scintillation vials containing $4 \mathrm{ml}$ of filtered $(0.45 \mu \mathrm{m}$ pore size) lake water and $5 \mathrm{mM}$ $\mathrm{Na}\left[1-{ }^{14} \mathrm{C}\right]$ acetate (specific activity $=37 \mathrm{MBq} \mathrm{mmol}^{-1}$ ) for $5 \mathrm{~h}$ at ambient lake water temperatures. Incorporation of $\left[{ }^{14} \mathrm{C}\right]$ acetate label was stopped by placing vials on ice and immediately filtering the contents. Filters and litter pieces were washed twice with $4 \mathrm{ml}$ of filtered lake water, placed in scintillation vials, and stored at $-20^{\circ} \mathrm{C}$ until analyzed. Frozen samples were lyophilized, weighed and ergosterol extracted and analyzed as above. Ergosterol fractions eluting from the HPLC column were collected in $20 \mathrm{ml}$ scintillation vials using an automated Pharmacia LKB Superfrac collection system. Collected fractions were mixed with $10 \mathrm{ml}$ of scintillation fluid (Scintillator Plus, CanberraPackard) and radioactivity was determined using a scintillation counter (Canberra-Packard, model 1600 CA) that automatically corrected for quenching. Acetate incorporation rates were converted to fungal growth rates assuming $12.6 \mu \mathrm{g}$ fungal biomass $\mathrm{nmol}^{-1}$ acetate incorporated, a value that has been established for fungi associated with standing dead leaves of the salt-marsh grass Spartina alterniflora (Newell et al. 2000).

Microbial respiration. Rates of microbial respiration associated with decomposing Phragmites australis litter were estimated from measurements of dissolved oxygen consumption. Subsamples of leaf blades and stem material were placed into glass chambers containing ca $30 \mathrm{ml}$ of membrane filtered $(0.2 \mu \mathrm{m})$ lake water. Changes in dissolved oxygen concentration within chambers were then monitored every $30 \mathrm{~s}$ for $30 \mathrm{~min}$ using oxygen microelectrodes (YSI, model 5357) connected to a data acquisition module and computer. All measurements were conducted in darkness at corresponding lake water temperatures. Additional chambers containing only filtered lake water were also monitored as controls. Respiration rates were calculated as the slope of regression lines from samples minus the slope of the control. Rates of $\mathrm{O}_{2}$ consumption were converted to rates of $\mathrm{CO}_{2}$ evolution, assuming a respiratory quotient $(\mathrm{RQ})$ of 1 . After respiration rates were determined, litter samples within chambers were dried at $105^{\circ} \mathrm{C}$ and AFDM determined.

DOC release. For determining rates of DOC release from decomposing litter, subsamples of leaf blades and stem litter were placed into $50 \mathrm{ml}$ Erlenmeyer flasks containing $20 \mathrm{ml}$ of membrane filtered $(0.2 \mu \mathrm{m})$ lake water. Samples were incubated for $24 \mathrm{~h}$ on a platform orbital shaker (50 rpm) in darkness at corresponding lake water temperatures. After incubation, samples were filtered through pre-ashed GF/F filters (Whatman). The resultant filtrates were collected, the volume measured, and samples transferred into preashed Schott tubes with Teflon-lined caps. Samples were preserved with concentrated phosphoric acid $\left(2 \mu \mathrm{ml}^{-1}\right.$ of sample volume), and kept at $4^{\circ} \mathrm{C}$ until analyzed for DOC using a Shimadzu TOC-5000 analyzer. After incubation, litter samples were dried at $105^{\circ} \mathrm{C}$ and sample AFDM determined. All values were corrected for DOC concentrations measured in non-littercontaining lake water controls.

\section{RESULTS}

\section{Litter decay and nutrient dynamics}

Rapid mass loss of Phragmites australis leaf blades was observed following submergence of leaf litter in

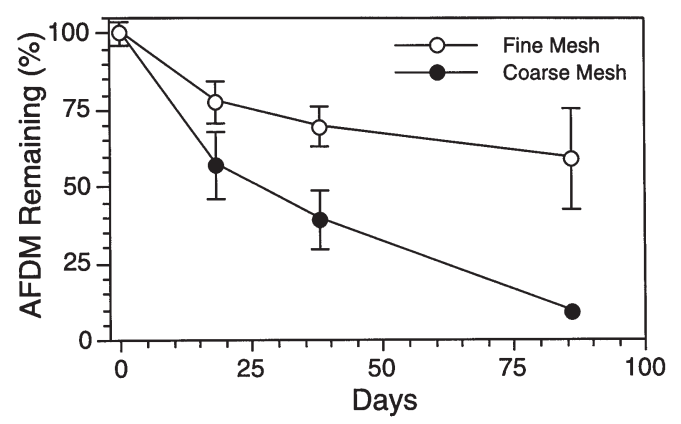

Fig. 1. Percent ash-free dry mass remaining (AFDM) of submerged Phragmites australis leaf litter enclosed in fine $(\mathrm{n}=2$ to 5 ) and coarse ( $\mathrm{n}=4$ to 5 ) mesh litter bags. Symbols indicate mean $\pm 1 \mathrm{SE}$ 
the reed stand (Fig. 1). Significant differences in rates of mass loss of leaf litter enclosed in fine and coarse mesh bags were also observed ( $p<0.05, t$-test), with over $90 \%$ of leaf mass loss occurring in coarse mesh bags within $86 \mathrm{~d}$, compared with a loss of only $40 \%$ in fine mesh bags. Respective decay rate coefficients $(-k)$ were $0.0273 \pm 0.0038$ (mean $\pm \mathrm{ASE}, \mathrm{r}^{2}=0.86$ ) and $0.0084 \pm 0.00017\left(r^{2}=0.53\right)$. Mass loss estimates of stem litter could not be determined reliably due to damage and partial loss of stem material from some of the litter bags.

Significant changes in leaf litter nutrient concentrations were observed during the study period, with both nitrogen $(\mathrm{N})$ and phosphorus $(\mathrm{P})$ concentrations of leaf litter enclosed in fine mesh bags increasing during decomposition. $\mathrm{N}$ concentrations in coarse mesh bags remained unchanged, and P concentrations decreased with time (Fig. 2). $\mathrm{N}$ and $\mathrm{P}$ concentrations in stem litter remained stable throughout the study, with no significant differences being observed for stem litter enclosed in either fine or coarse mesh bags (Fig. 3). However, both $\mathrm{N}$ and $\mathrm{P}$ concentrations in stem litter were 3 to $5 \times$ lower than the corresponding concentrations in leaf litter.

\section{Microbial biomass}

No significant differences in any of the measured microbial parameters were observed between litter
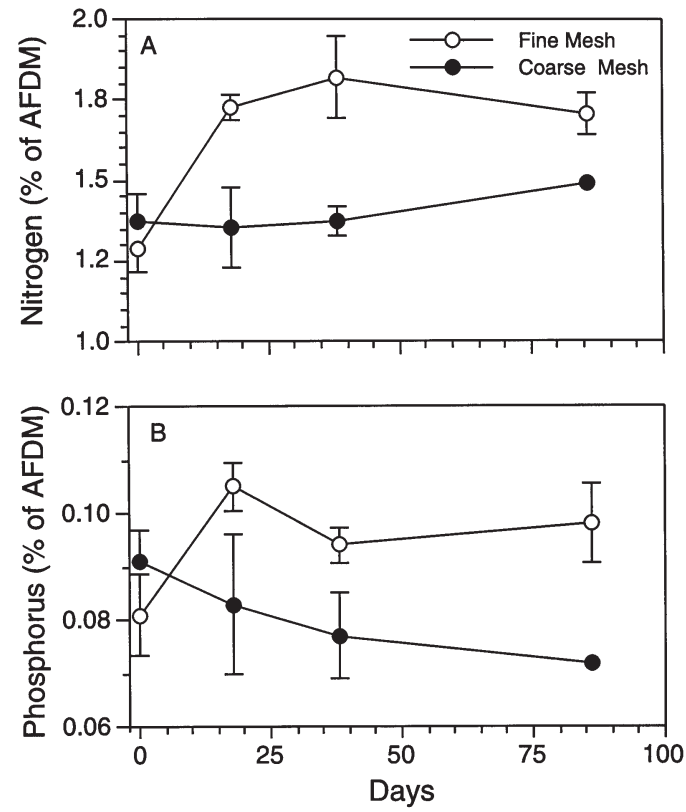

Fig. 2. Dynamics of (A) nitrogen and (B) phosphorus concentrations of submerged decomposing Phragmites australis leaf litter enclosed in fine ( $\mathrm{n}=3$ to 5 ) and coarse ( $\mathrm{n}=1$ to 6 ) mesh litter bags. Symbols indicate mean $\pm 1 \mathrm{SE}$
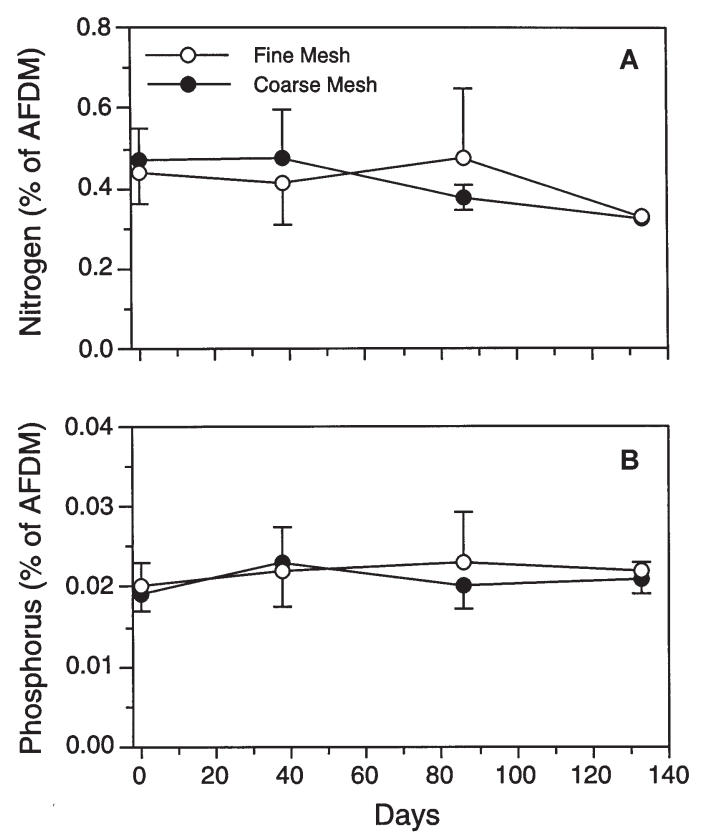

Fig. 3. Dynamics of (A) nitrogen and (B) phosphorus concentrations of submerged decomposing Phragmites australis stem litter enclosed in fine ( $\mathrm{n}=1$ to 4 ) and coarse ( $\mathrm{n}=3$ to 4 ) mesh litter bags. Symbols indicate mean $\pm 1 \mathrm{SE}$

enclosed in either fine or coarse mesh bags (paired $t$-test, $\mathrm{p}>0.10$ ). Therefore, data on fungal and bacterial biomass, fungal production, microbial respiration, and dissolved organic matter release from fine and coarse mesh bags were combined. Following litter submergence, fungal biomass associated with decaying Phragmites australis leaf blades initially increased to a maximum of $84 \pm 5 \mathrm{mg} \mathrm{C} \mathrm{g}^{-1}$ detrital C, but then subsequently decreased by over $40 \%$ by the last sampling date (Fig. 4A). In contrast, fungal biomass associated with decomposing stems remained unchanged and was 4 to $7 \times$ lower than corresponding biomass values observed in leaf litter (Fig. 5A). Maximum fungal biomass in decaying leaf and stem litter accounted for 8.4 and $1.2 \%$, respectively, of the total detrital mass.

Bacterial biomass associated with decaying leaf and stem litter of Phragmites australis increased significantly following submergence (Figs. 4A \& 5A). As noted for fungal biomass, similar differences in bacterial biomass were also observed between leaf and stem litter, with levels of bacterial biomass on stems 3 to $9 \times$ lower than corresponding biomass values on leaf litter (Figs. 4A \& 5A). Throughout the study period fungal biomass accounted for $\geq 90 \%$ of the total microbial biomass associated with both leaf and stem litter (Tables 2 \& 3). 

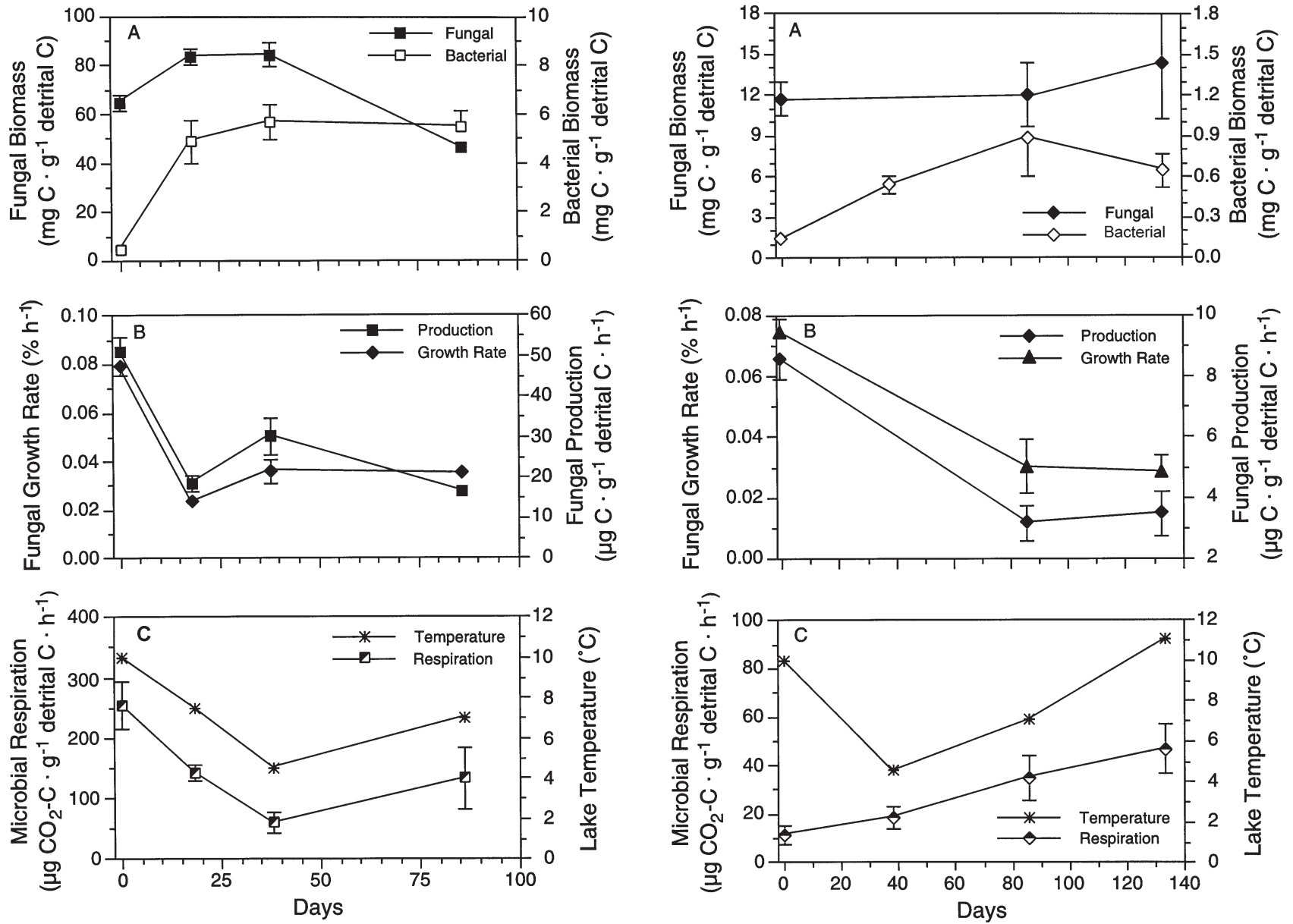

Fig. 4. Dynamics of (A) fungal and bacterial biomass, (B) fungal growth rates and production, and $(C)$ rates of microbial respiration associated with submerged decomposing Phragmites australis leaf litter. Changes in lake water temperatures during the study period are also illustrated (C). Symbols indicate mean $\pm 1 \mathrm{SE}(\mathrm{n}=3$ to 8$)$

Fig. 5. Dynamics of (A) fungal and bacterial biomass, (B) fungal growth rates and production, and $(\mathrm{C})$ rates of microbial respiration associated with submerged decomposing Phragmites australis stem litter. Changes in lake water temperatures during the study period are also illustrated (C). Symbols indicate mean \pm 1 SE $(n=4$ to 8$)$

Table 2. Characteristics of microbial assemblages associated with Phragmites australis leaves at different decomposition stages. Values indicate mean $\pm 1 \mathrm{SE}$ ( $\mathrm{n}=3$ to 8 ). $C_{0}=$ amount of leaf carbon initially present

\begin{tabular}{|c|c|c|c|c|}
\hline \multirow[t]{2}{*}{ Parameter } & \multicolumn{4}{|c|}{ Elapsed time (Day) } \\
\hline & 0 & 18 & 38 & 86 \\
\hline Fungal:bacterial biomass & $185 \pm 66$ & $23 \pm 6$ & $18 \pm 4$ & $12 \pm 3$ \\
\hline Fungal:microbial biomass (\%) & $99.3 \pm 0.2$ & $94.5 \pm 0.9$ & $93.6 \pm 0.9$ & $91.3 \pm 1.6$ \\
\hline Fungal turnover time $(\mathrm{d})$ & $53 \pm 3$ & $203 \pm 23$ & $134 \pm 19$ & $139 \pm 21$ \\
\hline Bacterial standing stock $\left(\mathrm{mg} \mathrm{C} \mathrm{g}^{-1} C_{0}\right)$ & $0.5 \pm 0.1$ & $3.8 \pm 0.8$ & $3.9 \pm 0.6$ & $3.3 \pm 0.7$ \\
\hline Fungal standing stock $\left(\mathrm{mg} \mathrm{C} \mathrm{g}^{-1} C_{0}\right)$ & $64.7 \pm 3.6$ & $64.9 \pm 6.2$ & $58.8 \pm 6.6$ & $29.6 \pm 6.3$ \\
\hline Fungal growth efficiency $(\%)^{\mathrm{a}}$ & $18 \pm 4$ & $13 \pm 1$ & $50 \pm 14$ & $40 \pm 30$ \\
\hline
\end{tabular}


Table 3. Characteristics of microbial assemblages associated with Phragmites australis stems at different decomposition stages. Stems initially held leaf sheaths, but these had entirely disappeared by the last collection date. Values indicate mean $\pm 1 \mathrm{SE}(\mathrm{n}=4$ to 5$)$

\begin{tabular}{|lccc|}
\hline Parameter & \multicolumn{3}{c|}{ Elapsed time (Day) } \\
& 0 & 86 & 133 \\
\hline Fungal:bacterial biomass & $92 \pm 19$ & $14 \pm 5$ & $23 \pm 6$ \\
Fungal:microbial biomass (\%) & $98.8 \pm 0.3$ & $89.6 \pm 3.5$ & $94.6 \pm 1.3$ \\
Fungal turnover time (d) & $57 \pm 3$ & $185 \pm 53$ & $172 \pm 34$ \\
Fungal growth efficiency (\%) & $49 \pm 11$ & $12 \pm 4$ & $6.8 \pm 0.3$ \\
aBased on the assumption that respiration was entirely fungal, i.e., fungal \\
growth efficiency = fungal production rate/(fungal production rate + micro- \\
bial respiration rate); values thus represent minimum estimates \\
\hline
\end{tabular}

stem litter were considerably lower $(<32 \%)$ than the corresponding rates observed from leaf litter.

\section{DOC release}

Release of DOC from Phragmites australis leaves was maximal (3.7 \pm $0.3 \mathrm{mg} \mathrm{C} \mathrm{g}^{-1}$ detrital $\mathrm{C} \mathrm{d}^{-1}$ ) prior to the submergence of litter bags in the reed stand (Fig. 6). However, by the first sampling date, rates of DOC release from leaf litter decreased significantly to $1.1 \pm 0.6 \mathrm{mg} \mathrm{C} \mathrm{g}^{-1}$ detrital $\mathrm{C} \mathrm{d}^{-1}$, increasing only slightly (but not signif-

\section{Fungal growth and production}

Instantaneous growth rates $(\mu)$ of fungi associated with leaf and stem litter were the highest prior to the submergence of standing plant litter in the reed stand (Figs. 4B \& 5B). Similar growth rates were observed for fungal assemblages inhabiting leaf $\left(1.9 \pm 0.1 \% \mathrm{~d}^{-1}\right)$ and stem $\left(1.7 \pm 0.1 \% \mathrm{~d}^{-1}\right)$ litter. Following submergence, growth rates associated with both leaf and stem litter decreased significantly, remaining relatively stable at around ca $0.7 \% \mathrm{~d}^{-1}$ during the remaining study period (Figs. 4B \& 5B). Rates of fungal biomass production associated with leaf and stem litter followed a similar pattern as growth rates, with the highest rates occurring at the beginning of the study period. Rates of production decreased following litter submergence, and fluctuated very little during the remaining study period. Due to the significantly higher fungal biomass in leaves, fungal production rates associated with leaf litter were 4 to $9 \times$ greater than those observed for stems.

\section{Microbial respiration}

Rates of microbial respiration associated with decaying Phragmites australis leaves decreased significantly from an initial maximum rate of $255 \pm 40 \mu \mathrm{g} \mathrm{C} \mathrm{g}^{-1}$ detrital $\mathrm{C} \mathrm{h}^{-1}$ to a minimum of $58 \pm 18 \mu \mathrm{g} \mathrm{C} \mathrm{g}^{-1}$ detrital $\mathrm{C} \mathrm{h}^{-1}$ after $38 \mathrm{~d}$ of litter submergence in the reed stand (Fig. 4C). Respiration rates then increased to a value roughly half of that observed at the beginning of the study $\left(130 \pm 51 \mu \mathrm{g} \mathrm{C} \mathrm{g}{ }^{-1}\right.$ detrital $\left.\mathrm{C} \mathrm{h}^{-1}\right)$. Changes in rates of respiration were similar to changes in lake water temperature (Fig. 4C). In contrast, rates of respiration associated with stem litter increased gradually during submerged litter decay, from an initial low rate of $11 \pm 4 \mu \mathrm{g} \mathrm{C} \mathrm{g}^{-1}$ detrital $\mathrm{C} \mathrm{h}^{-1}$ to a maximum of $46 \pm$ $10 \mu \mathrm{g} \mathrm{C}^{-1}$ detrital $\mathrm{C}^{-1}$ by the end of the study period (Fig. 5C). In addition, respiration rates associated with icantly) during the remaining study period. Release of DOC from stem litter was relatively stable during the first $86 \mathrm{~d}$ of the study period, ranging between 1.9 and $2.4 \mathrm{mg} \mathrm{C} \mathrm{g}^{-1}$ detrital $\mathrm{C} \mathrm{d}^{-1}$ (Fig. 6), but then decreased on the last sampling date.

\section{DISCUSSION}

\section{Microbial biomass and activity on standing Phragmites australis shoots}

The microbial parameters determined in the present study point to an appreciable microbial biomass and activity associated with newly collected litter (Day 0 samples) of the emergent macrophyte Phragmites australis. This finding supports results from previous studies quantifying microbial biomass and activity in several emergent macrophyte species, and suggests that considerable microbial colonization and decay of plant matter occur prior to the collapse of leaf and shoot material to the sediment-water interface (Newell et al. 1995, Bärlocher \& Biddiscombe 1996, Kuehn \& Suberkropp 1998b, Kuehn et al. 1999, Gessner 2000b).

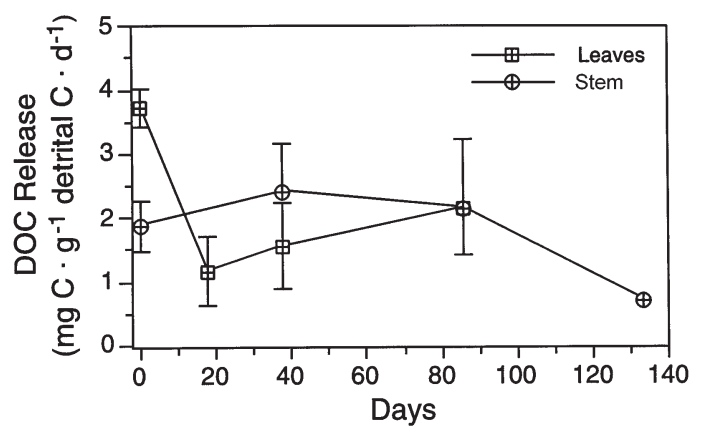

Fig. 6. Release of dissolved organic carbon (DOC) from submerged decomposing leaf and stem litter of Phragmites australis. Symbols indicate mean $\pm 1 \mathrm{SE}$ ( $\mathrm{n}=3$ to 8 ) 
Data of such quantitative studies are also in accordance with the fact that diverse fungal assemblages are present in standing dead shoots of both $P$. australis (Apinis et al. 1975, Poon \& Hyde 1998) and other emergent macrophytes (Pugh \& Mulder 1971, Kuehn \& Suberkropp 1998b).

\section{Microbial dynamics following litter submergence}

Submergence of Phragmites australis litter resulted in significant changes in the biomass and activities of litter-associated microbial assemblages. Fungal growth and production rates (leaves and stems) and microbial respiration rates (leaves only) decreased, whereas bacterial (leaves and stems) and fungal (leaves only) biomass first increased and then either remained relatively stable or decreased by the last sampling date. Similar dynamics following litter submergence have also been reported for microbial communities associated with the salt-marsh grass Spartina alterniflora (Newell et al. 1989) and the freshwater emergent macrophytes P. australis (Hargrave 1972, Andersen 1978, Tanaka 1991, 1993b) and Juncus effusus (Kuehn et al. 2000). For example, Hargrave (1972) observed initial increases in oxygen consumption by microbial assemblages inhabiting standing dead $P$. australis leaves during the first few days following submergence. This increase was followed by a sharp decline in rates of oxygen consumption, to a rate that was similar to benthic organic matter of unknown residence time (Hargrave 1972). Likewise, Kuehn et al. (2000) observed that fungal biomass and rates of fungal production associated with $J$. effusus decreased markedly following submergence of standing dead litter. These dynamics suggest that fungal assemblages (and possibly other microorganisms) that colonize plant material in an aerial environment may not perform well under permanently submerged conditions (Kuehn et al. 2000, see also Tanaka 1991, 1993b).
In contrast to leaves, stem material examined in the present study exhibited a steady increase in the rates of microbial respiration following litter submergence. This increase, together with the observed decrease in fungal growth and production rates, may point to an increasing contribution of bacteria to the mineralization of submerged stem litter. However, the opposing dynamics of respiration and fungal growth rates associated with stem litter could also be attributed to changes in fungal growth efficiencies (Table 3), perhaps in response to changes in fungal community structure, litter quality, environmental conditions, or a combination of these factors.

In the present study, fungal biomass per $g$ of leaf material remaining first increased following submergence of Phragmites australis litter, but because of the concomitant loss in leaf mass, fungal biomass per litter bag showed virtually no positive change during this initial decay period (Table 4). In addition, even stemassociated fungal biomass per $g$ of litter remaining remained unchanged over time. However, in spite of this zero or negative net production (as inferred from changes in standing stocks), fungal growth occurred in both leaf and stem litter throughout the study, with turnover times indicating moderate growth (Tables 2 \& $3)$. Interpolation and integration of production rates, as determined from rates of $\left[{ }^{14} \mathrm{C}\right]$ acetate incorporation, indicated that over the $86 \mathrm{~d}$ of the study, fungi produced $53 \pm 8\left(\right.$ mean \pm SD) $\mathrm{mg} \mathrm{C} \mathrm{g}^{-1}$ leaf carbon present when litter was submerged (Table 4 ). This production is equivalent to $82 \pm 17 \%$ of the fungal biomass initially present, when leaves were already heavily colonized. This percentage would be even higher in stems. Thus, it is clear that determination of fungal biomass is insufficient to assess the secondary production of fungi associated with submerged litter of $P$. australis. Rather, techniques involving measurement of instantaneous growth rates, such as the acetate-to-ergosterol method used in this study, are required to quantitatively assess the role of fungi in litter decomposition and their overall importance in detritus-based food webs.

Table 4. Estimates of parameters characterizing microbial performance on decomposing Phragmites australis leaves. Values indicate mean \pm 1 SE. $C_{0}=$ amount of leaf carbon initially present

\begin{tabular}{lccc} 
Parameter & \multicolumn{2}{c}{$\begin{array}{c}\text { Period (Days) } \\
0-38\end{array}$} & $0-86$ \\
\hline Bacterial net production $\left(\mathrm{mg} \mathrm{C} \mathrm{g}^{-1} \mathrm{C}_{0}\right)^{\mathrm{a}}$ & $0-18$ & $3.5 \pm 1.3$ & $2.9 \pm 1.6$ \\
Fungal net production $\left(\mathrm{mg} \mathrm{C}^{-1} C_{0}\right)^{\mathrm{a}}$ & $3.3 \pm 0.8$ & $-5.9 \pm 11.5$ & $-35.1 \pm 14.7$ \\
Cumulative fungal production $\left(\mathrm{mg} \mathrm{C} \mathrm{g}^{-1} C_{0}\right)$ & $0.2 \pm 7.2$ & $27 \pm 2$ & $53 \pm 3$ \\
Fungal yield coefficient $(\%)^{\mathrm{b}}$ & $15 \pm 1$ & $8.8 \pm 2.0$ & $13.0 \pm 3.8$ \\
${ }^{\mathrm{a}}$ As inferred from changes in standing stocks & & & \\
${ }^{\mathrm{b}}$ Cumulative fungal production/detrital carbon lost $\times 100$ & & & \\
& & & \\
\end{tabular}


The close correspondence between lake water temperature and leaf-associated respiration observed in the present study implies that the observed changes in respiratory activities were primarily governed by temperature. However, normalization of respiration rates to a standard temperature of $10^{\circ} \mathrm{C}$ (assumed $Q_{10}$ of 2 ) revealed that water temperatures accounted only for 10 to $36 \%$ of the observed changes in respiratory activity. Thus, in addition to temperature, changes in microbial community structure and/or temperature-independent activity appear also to have played a role in determining the observed temporal pattern.

\section{Microbial performance on leaf versus stem litter}

In the present study, significant differences in microbial biomass (fungi and bacteria) and rates of respiration were observed between decomposing leaf and stem litter, with stem material having substantially lower levels of microbial biomass and rates of respiration than leaf litter. Similar differences in microbial activities were reported by Andersen (1978), who found 4 to 9 times higher rates of oxygen consumption by microbial assemblages associated with submerged leaves of Phragmites australis than for stems. Such differences in microbial biomass and respiration between leaf and stem litter are not surprising given the fact that stems contain considerably more recalcitrant structural material (e.g., lignocellulose) and lower nutrient concentrations (N and P) (Polunin 1982, Gessner 2000a; see Figs. 4 \& 5). Both of these components of litter quality have been shown to affect the extent of microbial colonization and activity in other freshwater (Moran \& Hodson 1989, Sinsabaugh et al. 1993, Gessner \& Chauvet 1994) and marine litter decomposition systems (Newell et al 1996, Newell et al. 2000). However, of interest in the present study is that fungal growth rates were similar in leaf and stem litter, indicating that activity per unit biomass did not differ despite large differences in litter nutrient concentrations. These findings suggest that biomass accumulation may therefore be a critical process in determining the extent of fungal involvement in litter decomposition.

\section{Involvement of fungi in submerged litter decay}

Throughout the initial period of submerged litter decay, estimates of fungal biomass were 12 to 185 times greater than estimates of bacterial biomass, indicating that like in other freshwater systems (Newell 1993, Baldy et al. 1995, Newell et al. 1995, Sinsabaugh \& Findlay 1995, Weyers \& Suberkropp 1996, Kuehn et al. 2000) fungi are an important microbial assemblage involved in the decomposition of vascular plant matter. Although several indicators in the present study suggest that bacterial importance increased as litter decay proceeded, fungi also continued to grow and thus contributed to the decomposition of Phragmites australis leaves and stems under submerged conditions (see above).

The recognition of fungi as an important decomposer assemblage of submerged Phragmites australis litter is at partial variance with previous reports, which have postulated an equal or greater role of bacteria in the decomposition of emergent macrophytes (e.g., Mason 1976, Benner et al. 1986, Moran et al. 1988). Using selective inhibitors, Mason (1976) attempted to separate the respiratory activity of bacteria and fungi associated with submerged $P$. australis leaf litter. Results of his experiments suggested that fungi were as important as bacteria in the initial stages of decay but contributed very little to the overall litter mineralization in later stages when bacterial respiration increased significantly. Benner et al. (1986), also using selective inhibitors, examined the contributions of bacteria and fungi to the mineralization of granular lignocellulose derived from various emergent macrophytes and found that eukaryotes contributed only minimally to overall lignocellulose mineralization. This led Benner et al. (1986) and others (e.g., Mann 1988, Robertson et al. 1999) to conclude that bacteria are the primary decomposers of plant detritus in aquatic systems. However, in view of the absence of data on decomposition of intact tissue structures in the study of Benner et al. (1986) and the general problems associated with the use of so-called 'specific' inhibitors (Oremland \& Capone 1988), the diverging results between those and the present study may be partly due to differences in the underlying methodological approaches rather than to fundamental differences between systems (Newell 1993, Bärlocher 1997, Gessner et al. 1997). Simultaneous measurements of fungal and bacterial production have the potential to elucidate this issue further.

\section{Decomposition budget}

As a complement to the common mass loss approach, quantification of elemental fluxes to various decomposition products (e.g., $\mathrm{CO}_{2}, \mathrm{DOC}$, decomposer biomass) has been proposed to elucidate decay patterns, and thus improve our understanding of the overall decomposition process (Gessner et al. 1999). Data collected in the present study allow a partial construction of such a budget. Carbon dioxide and DOC were the major decomposition products observed throughout the study period. Together these fractions accounted for a very large proportion of the overall carbon loss from 
Table 5. Partial decomposition budget of submerged Phragmites australis leaves. For calculation of cumulative values, measured values were linearly interpolated between sampling dates and summed. Values indicate mean $\pm 1 \mathrm{SE}$. $C_{0}=$ amount of leaf carbon initially present

\begin{tabular}{|c|c|c|c|}
\hline \multirow[t]{2}{*}{ Parameter } & \multicolumn{3}{|c|}{ Period (Days) } \\
\hline & $0-18$ & $0-38$ & $0-86$ \\
\hline Detrital carbon lost $\left(\mathrm{mg} \mathrm{C} \mathrm{g}^{-1} C_{0}\right)$ & $225 \pm 139$ & $304 \pm 132$ & $409 \pm 167$ \\
\hline Cumulative $\mathrm{CO}_{2}$ release $\left(\mathrm{mg} \mathrm{C} \mathrm{g}^{-1} C_{0}\right)$ & $85 \pm 21$ & $135 \pm 28$ & $265 \pm 97$ \\
\hline Cumulative DOC release $\left(\mathrm{mg} \mathrm{C} \mathrm{g}^{-1} C_{0}\right)$ & $44 \pm 15$ & $71 \pm 29$ & $159 \pm 88$ \\
\hline Detrital carbon loss accounted for by release of $\mathrm{CO}_{2}$ plus DOC $(\%)^{\mathrm{a}}$ & $57 \pm 29$ & $68 \pm 25$ & $104 \pm 45$ \\
\hline${ }^{\mathrm{a}}$ Carbon released/detrital carbon lost $\times 100$ & & & \\
\hline
\end{tabular}

Phragmites australis leaves in fine mesh bags, with $\mathrm{CO}_{2}$ release being about twice as high as DOC release (Table 5). The overall budget with percentages between 57 and $104 \%$ of the observed carbon loss accounted for by $\mathrm{CO}_{2}$ and DOC appears to be plausible in view of the given uncertainties (i.e., relatively high variances) in the determination and interpolation of $\mathrm{CO}_{2}$ and DOC release rates, as well as in the estimation of litter mass loss. We also attempted to quantify carbon losses from litter in particulate form, but the gravimetric method adopted to estimate particulate organic carbon (POC) release was not sensitive enough to produce meaningful results (data not shown), perhaps because POC losses mediated by microbes were minor in the present study (but see discussion below on litter fragmentation by shear stress and large consumers).

Bacterial biomass per $g$ of leaf litter remaining initially increased 8.5-fold, equivalent to a nearly 2-fold increase in bacterial biomass per litter bag (Table 4). Incorporating these changes into the decomposition budget in Table 5 does not change values significantly. The net increase in bacterial carbon nevertheless indicates that some of the carbon released as $\mathrm{CO}_{2}$ flowed through the bacterial compartment. As indicated previously, fungal biomass per litter bag showed virtually no positive change during the study period and even decreased after Day 18 (Table 4 ). However, direct measurement of fungal growth and production demonstrated that fungi were a metabolically active assemblage within decaying litter. Therefore, despite the virtual lack of net changes in fungal biomass per litter bag, it is likely that a sizable portion of the carbon released from litter as $\mathrm{CO}_{2}$ flowed through the fungal compartment. Because of the much higher litter-associated biomass of fungi compared to bacteria, it is plausible that litter $\mathrm{CO}_{2}$ release through fungal activity may have surpassed bacterial carbon mineralization. These findings agree with results from studies on other decomposition systems (Baldy et al. 1995, Baldy \& Gessner 1997, Kuehn et al. 2000), suggesting that fungal assimilation can account for a large portion of the overall carbon loss from leaf litter in aquatic environments.

In the present study, leaf mass loss within coarse mesh bags was significantly faster than the corresponding losses observed in fine mesh bags. This contrasts with microbial activities and DOC release rates, which were similar in both types of bags. As a result, a large portion of leaf mass loss from coarse mesh bags is left unexplained. Compared to other studies on the decomposition of Phragmites australis leaves (see compilation in Gessner 2000a), mass loss from coarse mesh bags was rapid in Lake Neuchâtel, and visual inspection of retrieved litter bags indicated that much of these losses were probably a result of fragmentation. Specimens of the exotic crayfish Orconectes limosus were observed clinging to litter bags, suggesting that a portion of the enclosed leaf material may have been fragmented as a result of crayfish activity. Significant feeding on leaf litter by smaller macroinvertebrates was probably negligible, since macroinvertebrate densities in the reed stand appeared to be low. It is more likely, however, that considerable physical fragmentation was caused by intense shear stress during heavy wind and wave action, which is a common feature of the highly erosive south-eastern shore of Lake Neuchâtel where the study was conducted (Kocsis et al. 1999). Thus, in narrow fringes of macrophyte stands along the shores of large wind-exposed lakes, physical fragmentation of submerged plant litter and/or displacement to other parts of the lake may be as important as microbial decomposition at the production site.

Acknowledgements. The authors thank R. Illi for determination of litter nitrogen and phosphorus concentrations and E. Kaiser for help in DOC analysis. In addition, the authors thank Dr B. Pokorni-Aebi of the Environmental Protection Service, Canton Neuchâtel, for providing data on lake water chemistry, and C. Clerc of the Groupe d'Etude et de Gestion de la Grande Cariçaie for logistic support and permission to access the study site. This research was supported, in part, by a grant from the Swiss National Science Foundation (3100-050439.97). Support for D.K. was provided by a fellowship award for foreign students from the Swiss Federal Government. 


\section{LITERATURE CITED}

Andersen FØ (1978) Effects of nutrient level on decomposition of Phragmites communis Trin. Arch Hydrobiol 84: 42-54

Anesio AM, Denward CMT, Tranvik LJ, Granéli W (1999) Decreased bacterial growth on vascular plant detritus due to photochemical modification. Aquat Microb Ecol 17: 159-165

Apinis AE, Chesters CGC, Taligoola HK (1975) Microfungi colonizing nodes and internodes of aerial standing dead culms of Phragmites communis Trin. Nova Hedwigia 26: 495-507

Baldy V, Gessner MO (1997) Towards a budget of leaf litter decomposition in a first-order woodland stream. C R Acad Sci Paris Sér III 320:747-758

Baldy V, Gessner MO, Chauvet E (1995) Bacteria, fungi and the breakdown of leaf litter in a large river. Oikos 74 : 93-102

Bärlocher F (1997) Pitfalls of traditional techniques when studying decomposition of vascular plant remains in aquatic habitats. Limnetica 13:1-11

Bärlocher F, Biddiscombe NR (1996) Geratology and decomposition of Typha latifolia and Lythrum salicaria in a freshwater marsh. Arch Hydrobiol 136:309-325

Benner R, Moran MA, Hodson RE (1986) Biochemical cycling of lignocellulosic carbon in marine and freshwater ecosystems: relative contributions of prokaryotes and eukaryotes. Limnol Oceanogr 21:89-100

Denward CMT, Edling H, Tranvik LJ (1999) Effects of solar radiation on bacterial and fungal density on aquatic plant detritus. Freshw Biol 41:575-582

Dvoŕák J, Imhof G (1998) The role of animals and animal communities in wetlands. In: Westlake DF, Květ J, Szczepanski A (eds) The production ecology of wetlands. Cambridge University Press, Cambridge, p 211-318

Findlay S, Howe K, Austin HK (1990) Comparison of detritus dynamics in two tidal freshwater wetlands. Ecology 71: 288-295

Gessner MO (2000a) Breakdown and nutrient dynamics of submerged Phragmites shoots in the littoral zone of a temperate hardwater lake. Aquat Bot 66:9-20

Gessner MO (2000b) Mass loss, fungal colonisation and nutrient dynamics of Phragmites australis leaves during senescence and early decay in a standing position. Aquat Bot (in press)

Gessner MO, Chauvet E (1994) Importance of stream microfungi in controlling breakdown rates of leaf litter. Ecology 75:1807-1817

Gessner MO, Newell SY (1997) Bulk quantitative methods for the examination of eukaryotic organoosmotrophs in plant litter. In: Hurst CJ, Knudsen G, McInerney M, Stetzenbach LD, Walter MV (eds) Manual of environmental microbiology. American Society for Microbiology, Washington, DC, p 295-308

Gessner MO, Schmitt AL (1996) Use of solid-phase extraction to determine ergosterol concentrations in plant tissue colonized by fungi. Appl Environ Microbiol 62:415-419

Gessner MO, Suberkropp K, Chauvet E (1997) Decomposition of plant litter by fungi in marine and freshwater ecosystems. In: Wicklow DT, Söderström B (eds) The mycota: environmental and microbial relationships, Vol 4. Springer Verlag, Berlin, p 303-322

Gessner MO, Robinson CT, Ward JV (1998) Leaf breakdown in streams of an alpine glacial flood plain: dynamics of fungi and nutrients. J N Am Benthol Soc 17:403-419

Gessner MO, Chauvet E, Dobson M (1999) A perspective on leaf litter breakdown in streams. Oikos 85:377-384
Goulder R (1990) Extracellular enzyme activities associated with epiphytic microbiota on submerged stems of the reed Phragmites australis. FEMS Microbiol Ecol 73:323-330

Granéli W (1990) Standing crop and mineral content of reed, Phragmites australis (Cav.) Trin. ex Steud., in Swedenmanagement of reed stands to maximize harvestable biomass. Folia Geobot Phytotax 25:291-302

Hargrave BT (1972) Aerobic decomposition of sediment and detritus as a function of particle surface area and organic content. Limnol Oceanogr 17:583-596

Hietz P (1992) Decomposition and nutrient dynamics of reed (Phragmites australis (Cav.) Trin. ex steud.) litter in Lake Neusiedl, Austria. Aquat Bot 43:211-230

Kocsis O, Prandke H, Stips A, Simon A, Wüest A (1999) Comparison of dissipation of turbulent kinetic energy determined from shear and temperature microstructure. J Mar Syst 21:67-84

Kuehn KA, Suberkropp K (1998a) Diel fluctuations in microbial activity associated with standing dead leaf litter of the emergent macrophyte Juncus effusus. Aquat Microb Ecol 14:171-182

Kuehn KA, Suberkropp K (1998b) Decomposition of standing litter of the freshwater macrophyte Juncus effusus L. Freshw Biol 40:717-727

Kuehn KA, Gessner MO, Wetzel RG, Suberkropp K (1999) Decomposition and $\mathrm{CO}_{2}$ evolution from standing litter of the emergent macrophyte Erianthus giganteus. Microb Ecol 38:50-57

Kuehn KA, Lemke MJ, Wetzel RG, Suberkropp K (2000) Microbial biomass and production associated with decaying leaf litter of the emergent macrophyte Juncus effusus. Limnol Oceanogr 45:862-870

Květ J, Westlake DF (1998) Primary production in wetlands. In: Westlake DF, Květ J, Szczepański A (eds) The production ecology of wetlands. Cambridge University Press, Cambridge, p 78-268

Lee SY (1990) Net aerial primary productivity, litter production and decomposition of the reed Phragmites communis in a nature reserve in Hong Kong: management implications. Mar Ecol Prog Ser 66:161-173

Mann KH (1988) Production and use of detritus in various freshwater, estuarine and coastal marine ecosystems. Limnol Oceanogr 33:910-930

Mason CF (1976) Relative importance of fungi and bacteria in the decomposition of Phragmites leaves. Hydrobiologia 51:65-69

Mason CF, Bryant RJ (1975) Production, nutrient content and decomposition of Phragmites communis Trin. and Typha angustifolia L. J Ecol 63:71-95

Moran MA, Hodson RE (1989) Bacterial secondary production on vascular plant detritus: relationships to detritus composition and degradation rate. Appl Environ Microbiol 55: 2178-2189

Moran MA, Legovic T, Benner R, Hodson RE (1988) Carbon flow from lignocellulose: a simulation analysis of a detritus-based ecosystem. Ecology 69:1525-1536

Newell SY (1993) Decomposition of shoots of a saltmarsh grass: methodology and dynamics of microbial assemblages. Adv Microb Ecol 13:301-326

Newell SY, Fallon RD, Miller JD (1989) Decomposition and microbial dynamics for standing, naturally positioned leaves of the salt marsh grass Spartina alterniflora. Mar Biol 101:471-481

Newell SY, Moran MA, Wicks R, Hodson RE (1995) Productivities of microbial decomposers during early stages of decomposition of leaves of a freshwater sedge. Freshw Biol 34:135-148 
Newell SY, Arsuffi TL, Palm LA (1996) Misting and nitrogen fertilization of shoots of a saltmarsh grass: effects upon fungal decay of leaf blades. Oecologia 108:495-502

Newell SY, Blum LK, Crawford RE, Dai T, Dionne M (2000) Autumnal biomass and potential productivity of salt marsh fungi from $29^{\circ}$ to $43^{\circ}$ North latitude along the United States Atlantic coast. Appl Environ Microbiol 66:180-185

Oláh J (1972) Leaching, colonization and stabilization during detritus formation. Mem Ist Ital Idrobiol 29(Suppl): 105-127

Oremland RS, Capone DG (1988) Use of 'specific' inhibitors in biogeochemistry and microbial ecology. Adv Microb Ecol 10:285-382

Polunin NVC (1982) Processes contributing to the decay of reed (Phragmites australis) litter in fresh water. Arch Hydrobiol 94:182-209

Polunin NVC (1984) The decomposition of emergent macrophytes in fresh water. Adv Ecol Res 14:115-166

Poon MOK, Hyde KD (1998) Biodiversity of intertidal estuarine fungi on Phragmites at Mai Po Marshes, Hong Kong. Bot Mar 41:141-155

Porter KG, Feig YS (1980) The use of DAPI for identifying and counting aquatic microflora. Limnol Oceanogr 25:943-948

Pugh GJF, Mulder JL (1971) Mycoflora associated with Typha latifolia. Trans Br Mycol Soc 57:273-282

Robertson AI, Bunn SE, Boon PI, Walker KF (1999) Sources, sinks and transformations of organic carbon in Australian floodplain rivers. Mar Freshw Res 50:813-829

Simon M, Azam F (1989) Protein content and protein synthesis rates of planktonic marine bacteria. Mar Ecol Prog Ser 51:201-213

Sinsabaugh RL, Findlay S (1995) Microbial production, enzyme activity, and carbon turnover in surface sediments of the Hudson River estuary. Microb Ecol 30:127-141

Editorial responsibility: James Hollibaugh, Athens, Georgia, USA
Sinsabaugh RL, Antibus RK, Linkins AE, McClaugherty CA, Rayburn L, Repert D, Weiland T (1993) Wood decomposition: nitrogen and phosphorus dynamics in relation to extracellular enzyme activity. Ecology 74:1586-1593

Tanaka Y (1991) Microbial decomposition of reed (Phragmites communis) leaves in a saline lake. Hydrobiologia 220: $119-129$

Tanaka Y (1993a) Activities and properties of cellulase and xylanase associated with Phragmites leaf litter in a seawater lake. Hydrobiologia 262:65-75

Tanaka Y (1993b) Aerobic cellulolytic bacterial flora associated with decomposing Phragmites leaf litter in a seawater lake. Hydrobiologia 263:145-154

Tanaka Y, Tezuka Y (1982) Dynamics of detritus-attached and free-living bacteria during decomposition of Phragmites communis powder in seawater. Jpn J Ecol 32:151-158

Úlehlová B (1978) Decomposition processes in the fishpond littoral. In: Dykyjová D, Květ J (eds) Pond littoral ecosystems, structure and functioning. Springer-Verlag, Berlin, p 341-353

Úlehlová B (1990) Release and uptake of minerals during decomposition of plant litter in fish pond littoral. Folia Geobot Phytotax 25:303-308

Wetzel RG (1990) Land-water interfaces: metabolic and limnological regulators. Verh Int Ver Limnol 24:6-24

Wetzel RG, Howe MJ (1999) High production in a herbaceous perennial plant achieved by continuous growth and synchronized population dynamics. Aquat Bot 64:111-129

Weyers HS, Suberkropp (1996) Fungal and bacterial production during the breakdown of yellow poplar leaves in 2 streams. J N Am Benthol Soc 15:408-420

Wilkinson L, Hill MA, Welna JP, Birkenbeuel GK (1992) Systat 5 for the Macintosh. Version 5.2 edn. Systat Inc, Evanston, IL

Submitted: March 28, 2000; Accepted: August 18, 2000 Proofs received from author(s): October 5, 2000 